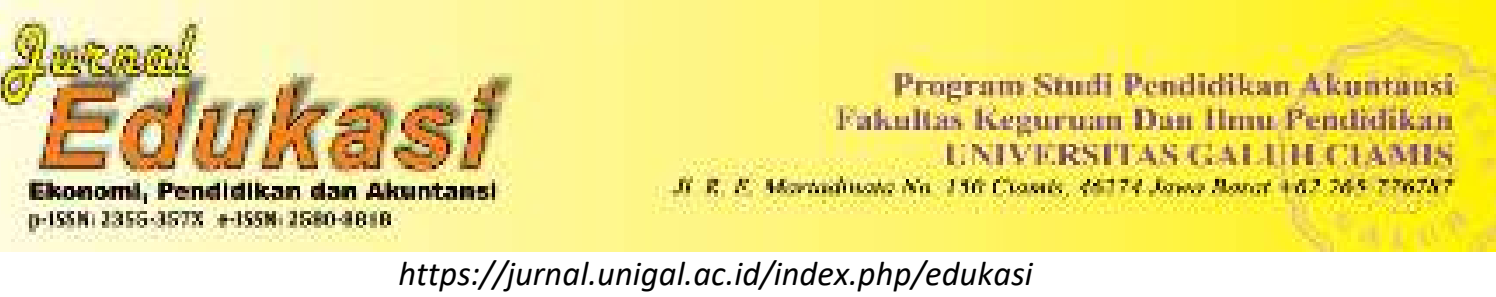

\title{
PERBEDAAN HASIL BELAJAR SISWA YANG MENERAPKAN MODEL PEMBELAJARAN KOOPERATIF TIPE EVERYONE IS A TEACHER HERE DENGAN TIPE GIVING QUESTION AND GETTING ANSWER PADA MATA PELAJARAN EKONOMI (Studi Eksperimen pada Kompetensi Dasar Menganalisis Perpajakan dalam Pembangunan Ekonomi Kelas XI IPS SMA Negeri 1 Baregbeg)
}

Oleh:

Rizka Andhika Putra ${ }^{1}$, Anggita Martina Pratama ${ }^{2}$

Pendidikan Akuntansi Universitas Galuh, Indonesia Email: rizkaandhikaputra@gmail.com

Sejarah Artikel: Diterima April 2019, Disetujui Mei 2019, Dipublikasikan Juni 2019

\begin{abstract}
ABSTRAK
Penelitian ini dilatarbelakangi bahwa rendahnya hasil belajar siswa. Beberapa faktor kendalanya yaitu kurangnya pemahaman siswa terhadap materi, proses belajar mengajar belum melibatkan siswa secara aktif, serta kurangnya inovasi dalam proses pembelajaran. Penelitian ini bertujuan untuk mengetahui: 1) Peningkatan hasil belajar siswa yang menerapkan model pembelajaran kooperatif tipe Everyone Is A Teacher Here pada pengukuran awal (pretest) dan pengukuran akhir (posttest). 2) Peningkatan hasil belajar siswa yang menerapkan model pembelajaran kooperatif tipe Giving Question And Getting Answer pada pengukuran awal (pretest) dan pengukuran akhir (posttest). 3) Perbedaan hasil belajar siswa yang menerapkan model pembelajaran kooperatif tipe Everyone Is A Teacher Here dengan tipe Giving Question And Getting Answer pada pengukuran akhir (posttest). Adapun metode yang digunakan yaitu eksperimen dengan Nonequivalence Control Group Design. Sedangkan uji analisis data menggunakan $\mathrm{N}$-Gain dan pengujian hipotesis menggunakan t-test. Hasil penelitian ini dapat disimpulkan bahwa penerapan model pembelajaran kooperatif tipe Everyone Is A Teacher Here dengan tipe Giving Question And Getting Asnwer dapat meningkatkan hasil belajar siswa dalam pembelajaran Ekonomi pada kelas XI IPS SMA Negeri 1 Baregbeg. Berdasarkan hasil penelitian diketahui: 1) Terdapat peningkatan hasil belajar siswa yang menerapkan model pembelajaran kooperatif tipe Everyone Is A Teacher Here pada pengukuran awal (pretest) sebesar 37,85 dan pengukuran akhir (posttest) sebesar 79,26 dengan rata-rata N-Gain bernilai 0,66 dengan kategori sedang. 2) terdapat peningkatan hasil belajar siswa yang menerapkan model pembelajaran kooperatif tipe Giving Question And Getting Answer pada pengukuran awal (pretest) sebesar 32,83 dan pengukuran akhir (posttest) sebesar 72,66 dengan rata-rata N-Gain 0,58 dengan kategori sedang. 3) Terdapat perbedaan hasil belajar siswa yang menerapkan model pembelajaran kooperatif tipe Everyone Is A Teacher Here dengan tipe Giving Question And Getting Answer pada pengukuran akhir (posttest).
\end{abstract}

Kata Kunci: Hasil Belajar, Giving Question and Getting Answer

\section{PENDAHULUAN}

Hasil belajar mempunyai peranan penting dalam proses pembelajaran. Hal ini disebabkan karena hasil belajar dapat dijadikan sebagai tolak ukur untuk mengetahui seberapa jauh perubahan pada diri siswa setelah menerima pengalaman belajarnya yang dapat diamati dan diukur dalam bentuk pengetahuan, sikap, dan keterampilan. Bloom (dalam Suprijono, 2017:6) Hasil belajar mencakup kemampuan kognitif, afektif, dan psikomotorik. Domain kognitif adalah knowledge (pengetahuan, ingatan), comprehension (pemahaman, menjelaskan, meringkas, contoh), application (menerapkan), analysis (menguraikan, menentukan hubungan), synthesis (mengorganisasikan, merencanakan, membentuk bangunan baru), dan evaluation (menilai). Domain afektif adalah receiving (sikap menerima), responding (memberikan respons), valuing (nilai), organization 
(organisasi), characterization (karakterisasi). Domain psikomotor meliputi initiatory, preroutine, dan rountinized. Sedangkan menurut Lindgren (dalam Suprijono, 2017:7): "Hasil pembelajaran meliputi kecakapan, informasi, pengertian, dan sikap".

Hasil dari proses belajar tercermin dalam prestasi belajar siswa yang diukur dari nilai yang diperoleh siswa setelah mengerjakan soal yang diberikan oleh guru pada saat evaluasi dilaksanakan. Namun pada kenyataannya masih banyak siswa yang memiliki hasil belajar yang rendah terutama pada mata pelajaran ekonomi. Hal ini disebabkan oleh berbagai faktor salah satunya adalah dalam pengemasan proses pembelajaran. Dalam pengemasan proses pembelajaran tersebut guru hanya menggunakan model pembelajaran konvensional dengan metode ceramah yang menyebabkan kurangnya perhatian dan antusias siswa dalam proses belajar mengajar. Proses pembelajaran pun masih berpusat pada guru yang didasarkan pada asumsi bahwa pengetahuan dapat dipindahkan secara utuh dari pikiran guru kepada peserta didik, dimana pengetahuan yang dipindahkan tersebut belum sebagai keterampilan berproses dan membangun pengetahuan yang lebih bermakna.

Jika melihat fakta dilapangan dan wawancara dengan guru Mata Pelajaran Ekonomi kelas XI IPS SMA Negeri 1 Baregbeg yaitu Bapak Encep pada Hari Senin, Tanggal 7, Bulan Januari Tahun 2019, Kecamatan Baregbeg, Kabupaten Ciamis, diketahui bahwa hasil belajar siswa terutama dalam Mata Pelajaran Ekonomi masih sangat rendah dan siswa cenderung kurang berani bertanya dan mengemukakan pendapat. Keadaan ini dapat disimpulkan bahwa hasil belajar siswa sangat dipengaruhi oleh model pembelajaran yang diterapkan oleh guru. Akan sangat terlihat bahwa guru kurang bervariasi dalam pemilihan model pembelajaran jika hanya menerapkan model pembelajaran konvensional secara terusmenerus karena mengakibatkan siswa tidak aktif ketika pembelajaran berlangsung dan diperkuat dengan adanya nilai perolehan siswa yang cenderung rendah.

Sependapat dengan Nurholis (2016: 113) bahwa hasil belajar peserta didik dalam ranah kognitif ini kurang pada peguasaan materi yang ditugaskan oleh gurunya.
Berbagai macam metode dan model pembelajaran harus diterapkan guna menarik perhatian siswa dalam belajar untuk meningkatkan prestasi belajarnya. Peranan metode ini tidak dapat dipisahkan dalam upaya peningkatan kualitas pendidikan. Salah satu aktivitas yang diduga dapat diterapkan untuk menumbuhkembangkan kemampuan siswa yaitu dengan menerapkan model pembelajaran Kooperatif tipe Everyone Is A Teacher Here (setiap orang adalah guru) dan tipe Giving Question And Getting Answer (memberi pertanyaan dan menerima jawaban).

Tindakan yang harus dilakukan untuk mengatasi permasalahan tersebut adalah dengan membandingkan inovasi pembelajaran menggunakan model pembelajaran kooperatif tipe Everyone Is A Teacher Here dengan tipe Giving Question And Getting Answer. Model pembelajaran Everyone Is A Teacher Here merupakan salah satu model pembelajaran kooperatif. Menurut Suprijono (2017:129) mengungkapkan bahwa: "Metode Everyone Is A Teacher Here merupakan cara tepat untuk mendapatkan partisipasi kelas secara keseluruhan maupun individual. Metode ini memberi kesempatan kepada setiap siswa untuk berperan sebagai guru bagi kawan-kawannya". Cara ini memberikan kesempatan kepada setiap peserta didik untuk berperan sebagai pendidik bagi kawan-kawannya. Melalui metode ini siswa dapat mengemukakan pendapatnya dan menjelaskan dengan bahasanya sendiri kepada teman-temannya sehingga dalam proses pembelajaran seluruh siswa akan aktif mengikuti pelajaran. Sedangkan metode Giving Question And Getting Answer dikembangkan untuk melatih peserta didik memiliki kemampuan dan keterampilan bertanya dan menjawab pertanyaan. (Suprijono, 2017:126)

Berdasarkan uraian diatas, permasalahan yang dialami siswa dalam hasil belajar dapat dilihat dari data hasil belajar siswa itu sendiri berupa nilai pada Mata Pelajaran Ekonomi Kelas XI IPS SMA Negeri 1 Baregbeg tahun pelajaran 2018/2019. Berikut ini disajikan tabel tentang nilai pada Mata Pelajaran Ekonomi Kelas XI IPS SMA Negeri 1 Baregbeg yang didapatkan pada saat melakukan wawancara dengan guru Mata Pelajaran Ekonomi kelas XI IPS SMA Negeri 1 Baregbeg yaitu Bapak Encep pada Hari Senin, Tanggal 7, Bulan Januari Tahun 2019, Kecamatan Baregbeg, Kabupaten Ciamis. 
Tabel 1:

Nilai Mata Pelajaran Ekonomi

Kelas XI IPS SMA Negeri 1 Baregbeg Tahun Ajaran 2018/2019

\begin{tabular}{ccccccccc} 
Kelas & $\begin{array}{c}\text { Jumlah } \\
\text { Siswa }\end{array}$ & $\begin{array}{c}\text { Nilai } \\
\text { Tertinggi }\end{array}$ & $\begin{array}{c}\text { Nilai } \\
\text { Terendah }\end{array}$ & $\begin{array}{c}\text { Nilai } \\
\text { rata- } \\
\text { rata }\end{array}$ & KKM & Tuntas & $\begin{array}{c}\text { Tidak } \\
\text { Tuntas }\end{array}$ & $\begin{array}{c}\text { Tidak } \\
\text { Tuntas } \\
(\%)\end{array}$ \\
\hline $\begin{array}{c}\text { XI } \\
\text { IPS 1 } \\
\text { XI }\end{array}$ & 27 & 72 & 40 & 61,04 & 65 & 9 & 18 & 66,67 \\
IPS 2 & 29 & 72 & 46 & 60,21 & 65 & 10 & 19 & 65,52 \\
\hline Total & 56 & & & & & 19 & 37 & 66,07
\end{tabular}

(Sumber : SMA Negeri 1 Baregbeg 2018/2019)

Berdasarkan daftar tabel 1.1 dapat dilihat bahwa kelas XI IPS di SMA Negeri 1 Baregbeg sebanyak dua kelas dengan jumlah siswa 56 orang. Keberhasilan belajar dilihat dari perolehan nilai yang mencapai KKM (Kriteria Ketuntasan Minimum). Nilai KKM untuk mata pelajaran ekonomi kelas XI IPS di SMA Negeri 1 Baregbeg adalah 65. Jika dilihat dari akumulasi nilai semester ganjil, mata pelajaran ekonomi untuk kelas XI IPS 1 siswa yang mendapatkan nilai dibawah KKM sebanyak 18 orang $(66,67 \%)$. Dan kelas XI IPS 2 siswa yang mendapatkan nilai dibawah KKM sebanyak 19 orang $(65,52 \%)$. Jika dikalkulasikan dari data yang diperoleh dari kelas XI IPS 1 dan XI IPS 2 yang mendapatkan nilai dibawah KKM sebanyak 37 orang $(66,07 \%)$.

Dengan adanya data diatas, diketahui bahwa nilai hasil belajar siswa kelas XI IPS SMA Negeri 1 Baregbeg pada mata pelajaran ekonomi belum optimal, jumlah siswa yang sudah mencapai KKM lebih sedikit dibandingkan jumlah siswa yang belum mencapai KKM. Untuk tercapainya tujuan pengajaran maka guru dapat menerapkan model pembelajaran yang dapat menarik minat belajar siswa dan meningkatkan hasil belajarnya yaitu menerapkan model-model pembelajaran yang tepat.

\section{METODE PENELITIAN}

Menurut Sugiyono (2018:2): "Metode penelitian pada dasarnya merupakan cara ilmiah untuk mendapatkan data dengan tujuan dan kegunaan tertentu".

Penelitian ini adalah penelitian eksperimen. Sugiyono (2018:72) menjelaskan bahwa: "Metode penelitian eksperimen dapat diartikan sebagai metode penelitian yang digunakan untuk mencari pengaruh perlakuan tertentu terhadap yang lain dalam kondisi yang terkendalikan". Penelitian ini termasuk pada penelitian Quasi Experimental Design (Eksperimen Semu) dengan Nonequivalence Control Group Design. Dalam penelitian ini ada dua kelompok sampel yaitu keduanya merupakan kelompok eksperimen. Peneliti dalam penelitiannya membagi dua kelas yaitu kelas eksperimen 1 dan kelas ekseperimen 2 . Pola tersebut digambarkan sebagai berikut:

Tabel 2:

Design Experiment

\begin{tabular}{cccc} 
Kelas & Test Awal & Treatment & Test Akhir \\
\hline Eksperimen 1 & $\mathrm{O}_{1}$ & $\mathrm{X}_{1}$ & $\mathrm{O}_{2}$ \\
Eksperimen 2 & $\mathrm{O}_{3}$ & $\mathrm{X}_{2}$ & $\mathrm{O}_{4}$
\end{tabular}

(Sumber :Sugiyono, 2018:79) 


\section{Peningkatan Hasil Belajar Siswa yang Menerapkan Model Pembelajaran Kooperatif Tipe Everyone Is A Teacher Here pada Pengukuran Awal (Pretest) dan Pengukuran Akhir (Posttest).}

Hasil belajar yang diperoleh siswa kelas eksperimen 1 yakni kelas XI IPS 1 yang menerapkan model pembelajaran kooperatif tipe Everyone Is A Teacher Here mencapai rata-rata yang baik apabila dilihat dari nilai kriteria ketuntasan minimum (KKM). Berdasarkan penelitian, penerapan model pembelajaran kooperatif tipe Everyone Is A Teacher Here pada mata pelajaran ekonomi kelas eksperimen 1 (XI IPS 1) SMA Negeri 1 Baregbeg menunjukkan adanya peningkatan dari hasil belajar siswa sebelum dan sesudah menggunakan model pembelajaran kooperatif tipe Everyone Is A Tecaher Here. Hal ini dapat dilihat dari peningkatan hasil belajar siswa pada pengukuran awal dengan pengukuran akhir. Peningkatan hasil belajar siswa dengan menggunakan model ini termasuk dalam kategori sedang. Berbeda dengan penelitian menurut Suparman (2012) pada kajian terdahulu yang pernah diteliti yaitu model pembelajaran kooperatif tipe Everyone Is A Teacher Here terhadap siswa dapat diketahui bahwa:

Penerapan metode pembelajaran aktif Everyone Is A Teacher Here di SMK Perindustrian Yogyakarta mengalami kenaikan ketuntasan klasikal hasil belajar siswa dari $60,7 \%$ meningkat menjadi $85,7 \%$. Ini memberikan bukti bahwa dengan metode yang diterapkan dan dilakukan oleh siswa dalam pembelajaran aktif Everyone Is A Teacher Here mampu meningkatkan hasil belajar siswa.

Peningkatan hasil belajar peserta didik tersebut terjadi karena model pembelajaran kooperatif tipe Everyone Is A Teacher Here merupakan model pembelajaran kooperatif yang memberikan kesempatan kepada setiap siswa untuk berperan sebagai pendidik bagi kawankawannya. Melalui metode ini siswa dapat mengemukakan pendapatnya dan menjelaskan dengan bahasanya sendiri kepada temantemannya sehingga dalam proses pembelajaran seluruh siswa akan aktif mengikuti pelajaran. Model pembelajaran ini mengembangkan keberanian dan keterampilan siswa dalam menjawab dan mengemukakkan pendapat.

Seperti halnya pendapat Djamarah dan Zain (2010:107) yang mengemukakan bahwa kelebihan strategi Everyone Is A Teacher Here adalah sebagai berikut: 1) Pertanyaan dapat menarik dan memusatkan perhatian siswa, sekalipun ketika itu siswa sedang ribut dan yang mengantuk kembali segar, 2) Merangsang siswa untuk melatih dan mengembangakan daya pikir, termasuk daya ingatan, dan 3) Mengembangkan keberanian dan keterampilan siswa dalam menjawab dan mengemukakkan pendapat.

\section{Peningkatan Hasil Belajar Siswa yang Menerapkan Model Pembelajaran Kooperatif Tipe Giving Question And Getting Answer pada Pengukuran Awal (Pretest) dan Pengukuran Akhir (Posttest).}

Hasil belajar yang diperoleh siswa kelas eksperimen 2 yakni kelas XI IPS 2 yang menerapkan model pembelajaran kooperatif tipe Giving Question And Getting Answer mencapai nilai rata-rata yang baik apabila dilihat dari nilai kriteria ketuntasan minimum (KKM). Hasil belajar siswa pada pengukuran awal (pretest) dan pengukuran akhir (posttest) memiliki peningkatan.

Sejalan dengan penelitian menurut Siti Mutmainah (2015) pada kajian yang pernah diteliti yaitu model pembelajaran kooperatif tipe Giving Question And Getting Answer terhadap keaktifan dan hasil belajar siswa dapat diketahui bahwa pengaruh peningkatan terhadap hasil belajar siswa setelah diterapkannya model pembelajaran kooperatif tipe Giving Question And Getting Answer. Hal ini terlihat dari ketuntasan klasikal hasil belajar siswa menunjukkan peningkatan dari $18 \%$ meningkat menjadi $82 \%$, dengan demikian indikator keberhasilan telah tercapai dengan baik.

Hal ini terjadi karena model pembelajaran kooperatif tipe Giving Question And Getting Answer menekankan kepada siswa untuk berperan aktif dalam proses pembelajaran, menumbuhkan keberanian mengajukan pendapat dan memberikan sanggahan, melatih daya pikir dan daya ingat siswa mengenai materi pelajaran yang telah diajarkan sebelumnya, memudahkan proses tanya jawab karena dibantu dengan kartu bertanya dan kartu menjawab sebagai alat peraga. Seperti yang dikemukakan oleh Effendi dan Siregar (2018:130) Kelebihan strategi Giving Question And Getting Answer adalah: 1) Suasana lebih menjadi aktif, 2) Siswa mendapat kesempatan baik secara individu maupun kelompok untuk menyampaikan hal-hal yang belum dimengerti, 3) Guru dapat mengetahui penguasaan siswa terhadap materi yang telah disampaikan, dan 4) Mendorong siswa untuk berani mengajukan pertanyaannya. 


\section{Perbedaan Hasil Belajar Siswa yang Menerapkan Model Pembelajaran Kooperatif Tipe Everyone Is A Teacher dengan tipe Giving Question And Getting Answer pada Pengukuran Akhir (Posttest).}

Hasil belajar siswa yang menerapkan model pembelajaran kooperatif tipe Everyone Is A Teacher Here pada kelas eksperimen 1 di kelas XI IPS 1 memiliki nilai rata-rata posttest lebih tinggi yaitu sebesar 79,60, dibandingkan dengan nilai rata-rata posttest siswa yang menggunakan model pembelajaran kooperatif tipe Giving Question And Getting Answer pada kelas eksperimen 2 di kelas XI IPS 2 yaitu sebesar 72,66. Hasil ini diperkuat dengan pengujian hipotesis yang menunjukkan bahwa nilai $t_{\text {hitung }}>$ $t_{\text {tabel }}$ atau 3,86 $>2,00$. Hal ini menunjukkan bahwa terdapat perbedaan hasil belajar siswa yang menerapkan model pembelajaran kooperatif tipe Everyone Is A Teacher Here dengan tipe Giving Question And Getting Answer.

Walaupun kedua metode pembelajaran ini sama-sama merupakan metode pembelajaran yang termasuk ke dalam model pembelajaran kooperatif dan sama-sama menggunakan kartu sebagai alat bantu, tetapi perbedaan hasil belajar siswa terjadi karena tingkat pemahaman dari masing-masing siswa berbeda-beda. Hal ini juga didasari oleh tingkat kondusifitas yang berbeda antara kelas XI IPS 1 dan kelas XI IPS 2.

Pada kelas eksperimen 1 (XI IPS 1) yang menerapkan model pembelajaran kooperatif tipe Everyone Is A Teacher Here, siswa belajar dengan kondusif dan tingkat pemahamannya cenderung tinggi. Suasana pembelajaran juga lebih menyenangkan dan interaktif karena banyak siswa yang berani mengemukakan pendapatnya. Dimulai dari pembagian kartu kepada masing-masing siswa, kemudian siswa menuliskan pertanyaan di kartu tersebut. Kartu yang sudah di isi pertanyaan dikumpulkan kembali kepada guru, kemudian guru membagikannya lagi kepada setiap siswa dengan tujuan siswa tidak mendapat pertanyaan yang dibuatnya sendiri. Banyak siswa yang berbondong-bondong ingin menjawab pertanyaan pada kartu dengan mengemukakan jawabannya secara lantang di depan kelas. Selain itu banyak juga siswa yang menyanggah atau mengemukakan pendapatnya jika jawaban yang dikemukakan siswa yang lain dirasa kurang tepat menurutnya. Seluruh siswa diwajibkan menjawab pertanyaan pada kartu yang dipegangnya, sehingga mereka akan berusaha mencari jawabannya. Dengan cara ini, siswa secara langsung dituntut untuk mengasah daya pikirnya.

Sedangkan pada kelas eksperimen 2 (XI IPS 2) yang menerapkan model pembelajaran kooperatif tipe Giving Question And Getting Answer, kartu yang dibagikan kepada tiap siswa yaitu dua kartu yang terdiri dari kartu bertanya dan kartu menjawab. Siswa yang akan bertanya menyerahkan kartu bertanya dan siswa yang akan menjawab menyerahkan kartu menjawab. Seluruh siswa dituntut untuk menghabiskan dua kartu yang digenggamnya, sehingga apabila ada siswa yang masih menyisakan kartu akan diberikan sanksi. Hal ini yang menjadikan siswa lebih aktif dan melatih kecepatan dan ketepatan menjawab pertanyaan dari siswa lain. Hal ini dikarenakan guru hanya sebatas mengulas dengan cara melengkapi jawaban siswa yang dirasa kurang tepat atau melengkapi jawaban siswa.

Metode pembelajaran merupakan salah satu hal penting dalam proses belajar mengajar, maka dari itu sebelum memberikan pembelajaran seorang pendidik perlu mempertimbangkan model dan metode pembelajaran yang akan digunakan dalam proses pembelajaran. Karena metode mengajar yang baik dapat mempengaruhi hasil belajar siswa. Selaras dengan pendapat dari Djamarah dan Zain (2010:75) yang menyatakan bahwa: "Guru sebaiknya menggunakan metode yang dapat menunjang kegiatan belajar mengajar, sehingga dapat dijadikan sebagai alat yang efektif untuk mencapai tujuan pembelajaran". Dengan demikian penerapan model pembelajaran kooperatif tipe Everyone Is A Teacher Here memiliki peran yang positif dalam meningkatkan hasil belajar siswa, karena hasil belajar siswa yang diperoleh dengan menerapkan model pembelajaran kooperatif tipe Everyone Is A Teacher Here lebih tinggi dibandingkan dengan penerapan model pembelajaraan kooperatif tipe Giving Question And Getting Answer.

\section{KESIMPULAN}

Berdasarkan penelitian yang dilakukan, penulis dapat menarik kesimpulan sebagai berikut:

1. Terdapat peningkatan hasil belajar siswa yang menerapkan model pembelajaran kooperatif tipe Everyone Is A Teacher Here pada mata pelajaran ekonomi di kelas eksperimen 1 (XI IPS 1) melalui pengukuran 
awal (pretest) dan pengukuran akhir (posttest), hal ini terlihat dari peran peserta didik lebih aktif, berani mengemukakan pendapat dan tingkat pemahaman siswa yang cenderung tinggi.

2. Terdapat peningkatan hasil belajar siswa yang menerapkan model pembelajaran kooperatif tipe Giving Question And Getting Answer pada mata pelajaran ekonomi di kelas eksperimen 2 (XI IPS 2) melalui pengukuran awal (pretest) dan pengukuran akhir (posttest), hal ini terlihat dari peran siswa lebih aktif, melatih rasa tanggung jawab dan melatih kecepatan dan ketepatan menjawab pertanyaa.

3. Terdapat perbedaan hasil belajar siswa yang menerapkan model pembelajaran kooperatif tipe Everyone Is A Teacher Here dengan tipe Giving Question And Getting Answer. Dari hasil posttest, tipe Everyone Is A Teacher Here lebih tinggi karena tingkat pemahaman siswa yang cenderung tinggi dan semua siswa berperan aktif dalam mengemukakan pendapatnya.

\section{DAFTAR PUSTAKA}

Djamarah, Syaiful Bahri. (2010). Guru \& Anak didik dalam Interaksi Edukatif. Jakarta: PT. Rineka Cipta.

Djamarah, Syaiful Bahri dan Zain, Aswan. (2010). Strategi Belajar Mengajar. Jakarta: PT. Rineka Cipta.

Effendi, Sulaiman dan Siregar, S.A. (2018). Penerapan Strategi Giving Question And Getting Answer sebagai Upaya Peningkatan Hasil Belajar Akuntansi: Penelitian Tindakan di Kelas X SMK ArRahman Medan. Jurnal Pendidikan Akuntansi. (Volume 1; 125-137)

Nurholis, Egi. (2016). Penerapan Model Pembelajaran Kooperatif Tipe STAD Dalam Pembelajaran Sejarah Untuk Meningkatkan Kreativitas Dan Hasil Belajar (Studi PTK pada Siswa Kelas XI di SMK Yasira Ciamis). Ciamis: Jurnal Artefak Vol. 4 No. 2 - Agustus 2016 [ISSN: 2355-5726] Hlm: 111-120

Sugiyono. (2013). Statistika untuk Penelitian. Bandung: Alfabeta, cv.

Sugiyono. (2015). Statistika untuk Penelitian. Bandung: CV. Alfabeta

Sugiyono. (2018). Metode Penelitian Kuantitatif, Kualitatif, dan $R \& D$. Bandung: Alfabeta.
Suparman. (2012). Penerapan Metode Pembelajaran Aktif Everyone Is A Teacher Here untuk Meningkatkan Keaktifan dan Hasil Belajar Kompetensi dasar Sistem Pengisian Kelas X SMK Perindustrian Yogyakarta 2011/2012. Skripsi. Yogyakarta: Program Studi Pendidikan Teknik Otomotif Fakultas Teknik Universitas Negeri Yogyakarta.

Suprijono, Agus. (2017). Cooperative Learning. Yogyakarta: Pustaka Belajar. 